OPEN ACCESS

Approved by:

Yousef Abu Kwaik,

University of Louisville, United States

*Correspondence:

Frontiers Editorial Office

editorial.office@frontiersin.org

Received: 15 November 2017 Accepted: 15 November 2017

Published: 17 November 2017

Citation:

Frontiers Editorial Office (2017)

Retraction: Synergistic combination of violacein and azoles that leads to enhanced killing of major human pathogenic dermatophytic fung Trichophyton rubrum Front. Cell. Infect. Microbiol. 7:496. doi: 10.3389/fcimb.2017.00496

\section{Retraction: Synergistic combination of violacein and azoles that leads to enhanced killing of major human pathogenic dermatophytic fungi Trichophyton rubrum}

\section{Frontiers Editorial Office*}

A retraction of the Original Research Article

Synergistic combination of violacein and azoles that leads to enhanced killing of major human pathogenic dermatophytic fungi Trichophyton rubrum

by Anju, S., Kumar, N. S., Krishnakumar, B., and Dileep Kumar, B. S. (2015). Front. Cell. Infect. Microbiol. 5:57. doi: 10.3389/fcimb.2015.00057

This paper is retracted by Frontiers. The publisher has discovered that the author(s) created and provided false information for the peer-review process. As the scientific integrity of the article cannot be guaranteed, and adhering to the recommendations of the Committee on Publication Ethics (COPE), the publisher therefore retracts the article.

The retraction of the article was approved by the Chief Editor of Frontiers in Cellular and Infection Microbiology.

Copyright $\odot 2017$ Frontiers Editorial Office. This is an open-access article distributed under the terms of the Creative Commons Attribution License (CC BY). The use, distribution or reproduction in other forums is permitted, provided the original author(s) or licensor are credited and that the original publication in this journal is cited, in accordance with accepted academic practice. No use, distribution or reproduction is permitted which does not comply with these terms. 